in vivo $35: 3233-3243(2021)$

doi:10.21873/invivo.12618

\title{
Kallikrein 11 Down-regulation in Breast Carcinoma: Correlation With Prognostic Parameters
}

\author{
TULIN OZTURK ${ }^{1}$, ECEM ZEYNEP KAIN ${ }^{1}$, METE BORA TUZUNER $^{2}$, AYCA DIREN $^{3}$, \\ SEBNEM BATUR $^{1}$, HULYA YILMAZ-AYDOGAN ${ }^{4}$, OGUZ OZTURK ${ }^{4}$ and TURGAY ISBIR ${ }^{5}$ \\ ${ }^{1}$ Department of Pathology, Cerrahpasa Medical School, Istanbul University Cerrahpasa, Istanbul, Turkey; \\ ${ }^{2}$ Research and Development Center, Acibadem Labmed Medical Laboratories, Istanbul, Turkey; \\ ${ }^{3}$ Department of Research and Development, Elips Healthcare Products, Istanbul, Turkey; \\ ${ }^{4}$ Department of Molecular Medicine, Aziz Sancar Institute of Experimental Medicine, \\ Istanbul University, Istanbul, Turkey; \\ ${ }^{5}$ Department of Medical Biology, Faculty of Medicine, Yeditepe University, Istanbul, Turkey
}

\begin{abstract}
Background: Expression of kallikrein-11 (KLK11) has been found to be related to the prognosis of various human cancer types but its physiological functions in the steps of breast cancer $(B C)$ progression are still unknown. Materials and Methods: BC and adjacent normal breast tissue samples were collected from 28 patients. KLK11 expression levels were determined by real-time polymerase chain reaction for each sample and associations with known prognostic features were statistically analyzed. Results: Although there was slight up-regulation in tumor tissues overall, significant down-regulation of KLK11 expression in tumor tissue was observed in the elderly and in patients with perineural invasion. Furthermore, tumor size, grade, mitotic score, necrosis, calcification, lymphatic invasion, hormone receptor status and Ki67 expression were associated with altered KLK11 level. Conclusion: Changes in expression levels of KLK11, associated with patient characteristics, might be used as complementary data in order to predict clinical outcome and prognosis in $B C$.
\end{abstract}

The involvement of extracellular proteolysis in tumor invasion and metastasis, through extracellular-matrix (ECM) degradation, has been acknowledged for a long time (1). The tumor microenvironment, including the ECM and stromal cells, acts as an essential modulator of tumor-cell

This article is freely accessible online.

Correspondence to: Tülin Öztürk, MD, Ph.D., Istanbul UniversityCerrahpasa Medical School, Cerrahpaşa Mah., Koca Mustafapaşa Cd., No:53, 34096, Fatih/Istanbul, Turkey. Tel: +90 5333472753, e-mail:dr.tulinozturk@gmail.com

Key Words: Kallikrein 11, KLK11, hK11, breast cancer. activities (2). Proteases of the extracellular milieu directly control and alter the tumor microenvironment and indirectly stimulate tumor-cell growth, apoptosis, angiogenesis, invasion and metastasis through irreversible cleavage of ECM and non-ECM components. Consequently, the complexity of cancer-related proteolysis in the extracellular space and its tumor-promoting/-suppressive effects in the long term are well known.

Among other components, the tissue kallikreins (KLKs), a family of serine proteases, is one of the key factors involved in modulating the tumor microenvironment. The serine protease family is the largest enzyme group that regulates various biological processes, and KLK genes comprise the biggest protease group in the human genome [reviewed in (3)]. The substrate specificity of KLKs is high and they also have proteolytic effects on arginine and lysine amino acids. Almost all KLKs have been detected in normal breast tissue $(4,5)$, with KLK6, -7, -8, -10, -11, and -14 having the highest levels of expression. The tumorassociated KLKs (mainly 1 to 15 ) are a focus for use as novel diagnostic, prognostic and predictive biomarkers for patients suffering from solid malignant tumors (6). Specifically in breast tumors and their tumor microenvironment, KLKs display different expression levels throughout the development and progression of breast cancer (2), moreover implying that they might be involved in regulating molecular mechanisms of breast cancer progression and metastasis.

KLK11 was firstly isolated from the human hippocampus and is assumed to be a predictive biomarker for prostate ovarian, and breast cancer (7-9). KLK11 is known to cleave few substrates compared to other types of proteases, which indicates it has a high degree of substrate specificity. Nonetheless there are no conclusive data on the physiological role of KLK11. 
in vivo $35: 3233-3243(2021)$

Table I. Recent studies showing kallikrein 11 (KLK11) expression levels in different cancer types.

\begin{tabular}{|c|c|c|c|c|c|}
\hline Author & $\begin{array}{l}\text { Tumor } \\
\text { type }\end{array}$ & $\begin{array}{c}\text { Number of } \\
\text { patients }\end{array}$ & Method & Results & Prognosis \\
\hline $\begin{array}{l}\text { Xiao Yu } \\
\text { et al. } 2010 \\
(11)\end{array}$ & $\begin{array}{l}\text { Low } \\
\text { rectal } \\
\text { carcinoma }\end{array}$ & 126 & $\mathrm{IHC}$ & $\begin{array}{l}\text { The degree of positive } \\
\text { immunohistochemical staining in } \\
\text { cancerous tissues was higher than } \\
\text { that in control tissues }\end{array}$ & $\begin{array}{l}\text { Patients with strong KLK11 } \\
\text { expression had poor prognosis }\end{array}$ \\
\hline $\begin{array}{l}\text { Jamaspishvilli } \\
\text { et al. } 2011 \\
\text { (12) }\end{array}$ & $\begin{array}{l}\text { Prostate } \\
\text { cancer }\end{array}$ & 70 & IHC & $\begin{array}{l}\text { Prostate cancer foci showed } \\
\text { reduced expression of KLK11 } \\
\text { compared with BPH per section } \\
\text { per patient }\end{array}$ & $\begin{array}{l}\text { Slight difference in KLK11 expression } \\
\text { between advanced and localized cases, } \\
\text { with up-regulation in advanced ones }\end{array}$ \\
\hline $\begin{array}{l}\text { Patsis et al. } \\
2012 \text { (13) }\end{array}$ & $\begin{array}{l}\text { Laryngeal } \\
\text { squamous } \\
\text { cell } \\
\text { carcinoma }\end{array}$ & 105 & RT-PCR & $\begin{array}{l}\text { KLK11 expression was found to } \\
\text { be lower in laryngeal primary and } \\
\text { recurrent cancerous samples, } \\
\text { compared to non-neoplastic specimens }\end{array}$ & $\begin{array}{l}\text { KLK11-positive tumor, either primary } \\
\text { or recurrent, was associated with } \\
\text { a significantly longer overall survival }\end{array}$ \\
\hline $\begin{array}{l}\text { Alexopoulou } \\
\text { et al. } 2014 \\
(14)\end{array}$ & $\begin{array}{c}\text { Primary } \\
\text { colorectal } \\
\text { adenocarcinoma }\end{array}$ & 120 & RT-PCR & $\begin{array}{l}\text { KLK11 mRNA was overexpressed } \\
\text { in colorectal adenocarcinomas } \\
\text { compared to non-neoplastic } \\
\text { counterparts }\end{array}$ & $\begin{array}{l}\text { KLK11 mRNA expression predicted poor } \\
\text { overall survival in colorectal adenocarcinoma, } \\
\text { as KLK11-positive patients were } \\
\text { at a 3-fold higher risk of death }\end{array}$ \\
\hline $\begin{array}{l}\text { Kolin et al. } \\
2015(15)\end{array}$ & $\begin{array}{l}\text { Gastric } \\
\text { cancer }\end{array}$ & 113 & IHC & $\begin{array}{l}\text { Expression of KLK11 was } \\
\text { cytoplasmic. Epithelial expression } \\
\text { was higher than stromaI }\end{array}$ & $\begin{array}{l}\text { Higher KLK11 expression was significantly } \\
\text { associated with worse survival in the subgroup } \\
\text { of patients with }>30 \text {-month survival }\end{array}$ \\
\hline $\begin{array}{l}\text { Unal et al. } \\
2016 \text { (16) }\end{array}$ & $\begin{array}{l}\text { Non-small } \\
\text { cell lung } \\
\text { cancer }\end{array}$ & 44 & IHC & $\begin{array}{l}\text { Immunohistochemical staining } \\
\text { for hK11 was positive } \\
\text { in all cases. }\end{array}$ & $\begin{array}{l}\text { Disease-free survival was higher in patients } \\
\text { strongly positive for hK11 than in those } \\
\text { weakly positive }\end{array}$ \\
\hline $\begin{array}{l}\text { Geng et al. } \\
2017 \text { (17) }\end{array}$ & $\begin{array}{l}\text { Advanced } \\
\text { high-grade serous } \\
\text { ovarian cancer } \\
\text { (FIGO stage } \\
\text { III/IV) }\end{array}$ & 139 & RT-PCR & $\begin{array}{l}\text { A highly significant positive } \\
\text { correlation was observed between } \\
\text { KLK9 and KLK15 as well asbetween } \\
\text { KLK10 and KLK11 mRNA } \\
\text { expression levels. }\end{array}$ & $\begin{array}{l}\text { Elevated KLK11 mRNA level was significantly } \\
\text { predictive for both longer OS and PFS, } \\
\text { indicating an about two-fold reduced probability } \\
\text { of death/progression in the high } \\
\text { KLK11-expressing group. }\end{array}$ \\
\hline $\begin{array}{l}\text { He et al. } \\
2019 \\
(18)\end{array}$ & $\begin{array}{l}\text { Esophageal } \\
\text { cancer }\end{array}$ & 100 & IHC & $\begin{array}{l}\text { KLK11 expression was significantly } \\
\text { lower in tumor tissues compared } \\
\text { with adjacent non-tumor tissues }\end{array}$ & $\begin{array}{c}\text { Patients with low expression of KLK11 } \\
\text { had a higher survival rate than patients } \\
\text { with high expression }\end{array}$ \\
\hline
\end{tabular}

BPH: Benign prostatic hyperplasia; hK11: human kallikrein 11; FIGO: International Federation of Obstetrics and Gynecology; IHC: immunohistochemistry; OS: overall survival; PFS: progression-free survival.; RT-PCR: real-time polymerase chain reaction

Regardless of therapy, prognostic factors can provide vital information about clinical outcomes of patients at the time of diagnosis. Tumor growth, its potential to be invasive and metastatic can rely on such factors. Traditional prognostic factors for breast cancer include the nuclear and histological grade, axillary lymph node status, tumor size, hormone receptor statuses [estrogen (ER), progesterone (PR) and human epidermal growth factor receptor 2 (HER2)] and Ki67-defined proliferation index are well-recognized prognostic factors for breast cancer, of which the latter two are the most clinically relevant. Although these factors have a great impact on risk assessment, targeted therapies and individualized treatment (10), there is still a need for the integration of molecular prognostic factors in order to improve clinical decision-making.

An alteration in the level of KLK11 expression was acknowledged to be a possible prognostic biomarker for several cancer types, such as of the prostate, lung, larynx, stomach, ovary and colon, during the past decade (Table I).
Although its mRNA expression has been shown in breast tissue (19), data concerning a prognostic role for KLK11 in breast cancer are still limited. Current knowledge about KLK11 mRNA expression in breast tumor, which was shown to be similar (20) compared to healthy breast tissue over a decade ago, indicates a significant difference between histological grade I/II and grade III breast tumors. This was associated with degradation of insulin-like-factor (IGF)binding-protein 3 by KLK11, thus providing growth factors for breast cancer progression (20). Activation of B1 bradykinin receptor was shown to stimulate overexpression of KLK11 in an $\mathrm{ER}^{+}$breast cancer cell line (21). In addition, another study showed 30-fold up-regulation of KLK11 level when $\mathrm{ER}^{+}$breast cancer cells acquired metformin resistance (22). Whether KLK11 is associated with good or poor prognosis of patients with breast cancer remains to be elucidated.

Based on this current knowledge, we aimed to investigate the potential role of KLK11 as a prognostic biomarker for 
Ozturk et al: Kallikrein 11 Down-regulation and Prognosis in Breast Carcinoma

breast cancer by comparing KLK11 gene expression levels in tumor and adjacent tumor-free tissues among patients with breast cancer. Furthermore, we evaluated our results together with the current prognostic characteristics.

\section{Materials and Methods}

Clinical samples. In this study, we included patients who underwent surgery at the General Surgery Department of Istanbul University-Cerrahpasa Faculty of Medicine between 2011 and 2013. Pathological examination to diagnose and confirm the correct sampling of tumor and adipose tissue were performed at the Pathology Department of Istanbul University-Cerrahpasa Faculty of Medicine. One tumor and one non-tumor tissue sample were obtained from each patient and snap-frozen in liquid nitrogen. All samples were stored at $-80^{\circ} \mathrm{C}$ until use for the extraction of total RNA.

The stages and grades of the tumors were classified according to the American Joint Committee on Cancer/Union for International Cancer Control TNM classification and stage groupings (23). All data for the samples, including age, tumor type, number of tumor foci, histological grade, necrosis, calcification, lymphatic invasion, perineural invasion, tumor margins and the status of receptors (ER, PR and HER2) were recorded. Immunohistochemical staining was performed for ER, PR, HER2 and Ki67, as well as hematoxylineosin, on tumor samples. silver DNA in situ hybridization was performed when the HER2 score was $2+$.

All procedures performed in this study were in accordance with the ethical standards of the institutional and/or National Research Committee and with the Declaration of Helsinki (2013). All patients provided written informed consent to participate in this study, which was approved by The Scientific Research Projects Ethical Board of Istanbul University-Cerrahpaşa Faculty of Medicine (Protocol No: 2012/259-949).

Immunohistochemical staining. Three-micrometer-thick sections from paraffin-embedded-blocks fixed in $10 \%$ formaldehyde were placed on positively charged slides. All immunohistochemistry staining procedures, including deparaffinization and antigen release stages, were performed on an automated immunohistochemistry staining machine (Ventana Benchmark XT, Ventana Medical Systems, Tuscon, AZ, USA) according to manufacturer's instructions, using dilutions of 1/100-1/400 for ER (clone SP1; Thermo-Scientific, Richard Allan Scientific Co, Kalamazoo, MI, USA), 1/100-1/200 for PR (clone 16; Novocastra, Leica Biosystems, Newcastle, UK), and 1/100 for HER2 (clone SP3; ThermoScientific, Richard Allan Scientific Co). The counter staining was applied with hematoxylin solution in the staining device and the process was completed after the dehydration and xylene steps. The positivity or negativity of staining with each antibody was determined for all cases. Nuclear staining of $>10 \%$ of cells was accepted as positivity for ER and PR status. For HER2, more than $30 \%$ staining was scored as +3 and cases were considered to be receptor-positive.

Extraction of total RNA and cDNA synthesis. The procedure for RNA extraction was as described before (24). Briefly, frozen tissue samples $(\sim 100 \mathrm{mg})$ were pulverized to fine powder with liquid nitrogen. TRIzol reagent (Fisher Scientific, Pittsburgh, PA, USA) was used in conjunction with PureLink RNA Mini Kit (Thermo
Table II. Prognostic features of the study patients.

\begin{tabular}{|c|c|c|}
\hline Characteristic & & Value \\
\hline Age, years & Mean \pm SD (range) & $58 \pm 2.70(33-83)$ \\
\hline Largest tumor diameter, $\mathrm{cm}$ & Mean $\pm \mathrm{SD}$ (range) 2 & $2.25 \pm 0.22(0.7-6.5)$ \\
\hline \multirow[t]{3}{*}{ Operation type, n (\%) } & $\mathrm{BM}$ & $4(14)$ \\
\hline & PM & $11(40)$ \\
\hline & MRM & $13(46)$ \\
\hline \multirow[t]{3}{*}{ Tumor type, n (\%) } & Invasive ductal & $24(86)$ \\
\hline & Invasive lobular & $1(4)$ \\
\hline & Mixed type & $3(10)$ \\
\hline \multirow[t]{2}{*}{ Histological grade, n (\%) } & II & $15(54)$ \\
\hline & III & $13(46)$ \\
\hline \multirow{2}{*}{ Necrosis, $\mathrm{n}(\%)$} & Present & $10(36)$ \\
\hline & Absent & $18(64)$ \\
\hline \multirow[t]{2}{*}{ Calcification, n (\%) } & Present & $10(36)$ \\
\hline & Absent & $18(64)$ \\
\hline \multirow[t]{2}{*}{ Lymphatic invasion, $\mathrm{n}(\%)$} & Present & $18(64)$ \\
\hline & Absent & $10(36)$ \\
\hline \multirow[t]{2}{*}{ Perineural invasion, $\mathrm{n}(\%)$} & Present & $19(68)$ \\
\hline & Absent & $9(32)$ \\
\hline \multirow[t]{2}{*}{ Tumor margins, $\mathrm{n}(\%)$} & Infiltrative & $24(86)$ \\
\hline & Infiltrative+expansile & $4(14)$ \\
\hline \multirow[t]{2}{*}{ Multiple foci, n (\%) } & Present & $13(46)$ \\
\hline & Absent & $15(54)$ \\
\hline \multirow[t]{2}{*}{$\mathrm{ER}, \mathrm{n}(\%)$} & Negative & $3(11)$ \\
\hline & Positive & $25(89)$ \\
\hline \multirow[t]{2}{*}{ PR, n (\%) } & Negative & $8(29)$ \\
\hline & Positive & $20(71)$ \\
\hline \multirow[t]{2}{*}{ HER-2/neu, n (\%) } & Negative & $7(25)$ \\
\hline & Positive & $21(75)$ \\
\hline \multirow[t]{3}{*}{ Ki67, n (\%) } & High & $19(68)$ \\
\hline & Borderline & $6(21)$ \\
\hline & Low & $3(11)$ \\
\hline
\end{tabular}

BM: Bilateral mastectomy; ER: estrogen receptor; HER2/neu: human epidermal growth factor receptor 2; MRM: modified radical mastectomy; PM: partial mastectomy; PR: progesterone receptor.

Fisher Scientific, Waltham, MA, USA) to isolate RNA from samples. RNA concentrations were measured with a NanoDrop 1000 spectrophotometer (Thermo Scientific). cDNA synthesis was achieved according to kit manufacturer protocol (Applied Biosystems, Carlsbad, CA, USA). The total RNA concentration was adjusted to $100 \mathrm{ng} /$ reaction.

Reverse transcription polymerase chain reaction (RT-PCR) assay. RT-PCR analysis was performed according to the protocol of the TaqMan Gene Expression Assay (Applied Biosystems) by using an Applied Biosystems 7500 RT- PCR instrument. Actin beta (ACTB) gene was used as the internal control. The primer sequences for RTPCR were as follows: KLK11, forward primer: 5'-CCG CTA CAT AGT TCA CCT GG-3', reverse primer: 5'-AGG TGT GAG GCA GGC GTA ACT-3'; ACTB, forward primer: 5'-TGC ATT GAC AAC GAG GC-3', reverse primer: 5'-CTG TCT TGA CAT TGT TG-3'. Briefly, $10 \mu \mathrm{l}$ of total PCR reaction contained $5 \mu \mathrm{l}$ of TaqMan Gene Expression Master Mix, $0.5 \mu \mathrm{l}$ of primer mix, $2 \mu \mathrm{l}$ of cDNA template, and $2.5 \mu \mathrm{l}$ RNase-free water. PCR reaction was conducted as follows: $50^{\circ} \mathrm{C}$ for $2 \mathrm{~min}$ for uracil $\mathrm{N}$-glycosylase incubation, $95^{\circ} \mathrm{C}$ for $10 \mathrm{~min}$ for polymerase activation, and then 40 


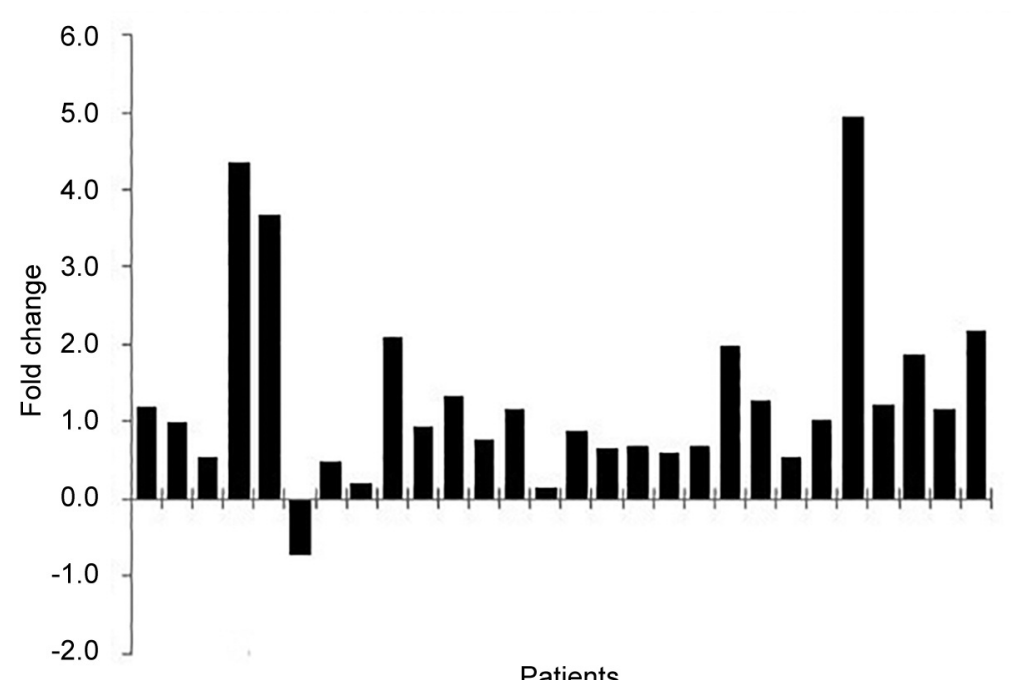

Patients

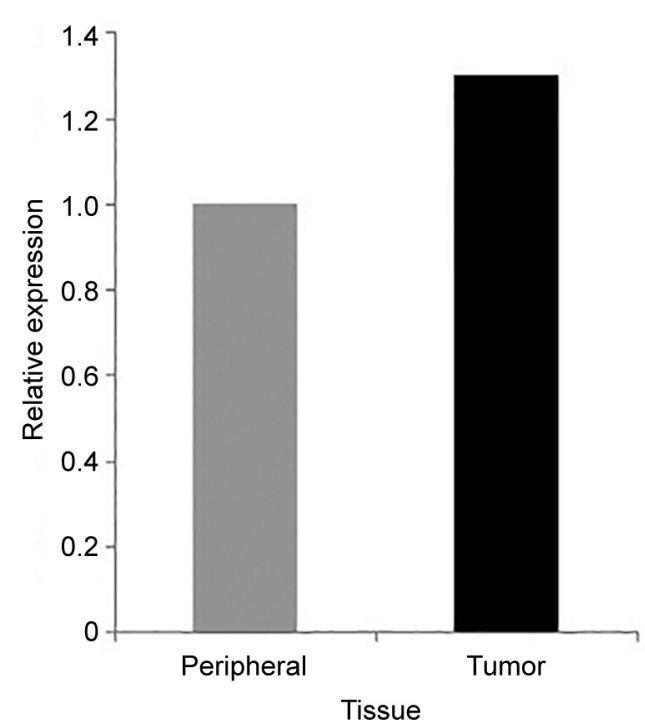

Figure 1. Kallikrein 11 expression levels in tumor tissue relative to normal peripheral tissue among patients with breast cancer.

cycles at $95^{\circ} \mathrm{C}$ for $15 \mathrm{~s} / 60^{\circ} \mathrm{C}$ for $1 \mathrm{~min}$. All samples were studied as triplicates. Relative quantitation of gene expression was calculated using the $\Delta \Delta \mathrm{Ct}$ method (25).

Statistical analysis. Associations between the expression levels and the clinicopathological parameters were tested with Fisher's exact test (FE) or Mann-Whitney $U$-test (MU) when appropriate. A twosided value of $p<0.05$ was deemed statistically significant. Statistical analyses were performed using SPSS 21 software (IBM Corp., Armonk, NY, USA).

\section{Results}

Patient characteristics. Tumor and adjacent normal breast tissue ( 200 mg) samples were collected from 28 female patients who were diagnosed with invasive breast cancer and underwent mastectomy or breast-conserving surgery at Istanbul University-Cerrahpasa Faculty of Medicine during the period of February 2011-May 2013. The patients included in the study did not receive adjuvant chemotherapy before surgery and their mean age was $58 \pm 2.70$ years (range $=33-83$ years). Other clinicopathological parameters are given in Table II. Most of the patients had invasive ductal carcinoma (86\%) and ER/PR-positive receptor status, which is the most common form of breast cancer. A high rate of Ki67 expression was observed in most tumors. Regarding the histological grades, they were almost equally distributed between II and III. The presence of lymphatic or perineural invasion was detected in the majority of the cases. In contrast, necrosis and calcification were observed less frequently.
KLK11 mRNA expression and its association with prognostic features. The expression levels in tumor were compared to non-tumor from 28 patients. Except for one patient, all the others showed the same pattern of KLK11 expression. Overall, KLK11 expression was found to be 1.3-fold higher in tumor compared to non-tumor tissue (Figure 1).

We further examined the possible associations of clinicopathological parameters by defining three groups according to the KLK11 expression level: Down-regulated: down-regulation by two-fold or more compared to the paired peripheral tissues); no alteration: change of expression by less than two-fold down-/up-regulation compared to the paired peripheral tissues; and up-regulated: up-regulation by 2-fold or more compared to the paired peripheral tissues (Table III). Groups showing significant expression differences are shown in Figure 2 and Figure 3.

Age of the patients and presence of perineural invasion were observed to be associated with two-fold or more downregulation of $K L K 11$ [Figure 2, $p=0.042$ and $p=0.009$ (FE), respectively]. Down-regulation was also found to be associated with having a larger tumor diameter $(\geq 2 \mathrm{~cm})$ (Figure 3A, $p=0.0032$ ), higher tumor grade (Figure 3B, $p=0.0029 \mathrm{MU}$ ), mitotic score $>1$ (Figure $3 \mathrm{C}, p=0.0007 \mathrm{MU}$ ), calcification (Figure 3E, $p=0.0014 \mathrm{MU}$ ), lymphatic invasion (Figure 3F, $p=0.0041 \mathrm{MU}$ ), $\mathrm{PR}^{+}$(Figure 3H, $p=0.0001 \mathrm{MU}$ ), HER2 $^{-}$(Figure 3I, $p<0.00001 \mathrm{MU}$ ) and high Ki67 level (Figure 3J, $p=0.0017 \mathrm{MU}$ ).

Only two relatively good prognostic parameters, which were the absence of necrosis (Figure 3D) and the presence of ER (Figure 3G), were associated with KLK11 up- 
Table III. Distribution of kallikrein 11 expression levels according to prognostic features.

\begin{tabular}{|c|c|c|c|c|}
\hline Characteristic & & $\begin{array}{c}\text { Down-regulated, } \\
\mathrm{n}(\%)\end{array}$ & $\begin{array}{c}\text { No alteration, } \\
\mathrm{n}(\%)\end{array}$ & $\begin{array}{c}\text { Up-regulated, } \\
\mathrm{n}(\%)\end{array}$ \\
\hline \multirow[t]{2}{*}{ Age } & $<50$ Years & $2(25)$ & $5(63)$ & $1(12)$ \\
\hline & $\geq 50$ Years & $10(50)$ & $3(15)$ & 7 (35) \\
\hline \multirow[t]{2}{*}{ Tumor diameter } & $<2 \mathrm{~cm}$ & $3(38)$ & $5(62)$ & $0(0)$ \\
\hline & $\geq 2 \mathrm{~cm}$ & $9(45)$ & $3(15)$ & $8(40)$ \\
\hline \multirow[t]{3}{*}{ Tumor type } & Invasive ductal & $12(50)$ & $7(29)$ & $5(21)$ \\
\hline & Invasive lobular & $0(0)$ & $0(0)$ & $1(100)$ \\
\hline & Mixed type & $0(0)$ & $1(33)$ & $2(64)$ \\
\hline \multirow[t]{2}{*}{ Histological grade } & II & $4(27)$ & $5(33)$ & $6(40)$ \\
\hline & III & $8(62)$ & $3(23)$ & $2(15)$ \\
\hline \multirow[t]{2}{*}{ Mitotic score } & $>1$ & $9(53)$ & $5(29)$ & $3(18)$ \\
\hline & 1 & $3(27)$ & $3(27)$ & $5(46)$ \\
\hline \multirow[t]{2}{*}{ Necrosis } & Present & $6(60)$ & $3(30)$ & $1(10)$ \\
\hline & Absent & $6(33)$ & $5(28)$ & $7(39)$ \\
\hline \multirow[t]{2}{*}{ Calcification } & Present & $7(58)$ & $2(17)$ & $3(25)$ \\
\hline & Absent & $5(31)$ & $6(38)$ & $5(31)$ \\
\hline \multirow[t]{2}{*}{ Lymphatic invasion } & Present & $8(44)$ & $4(22)$ & $6(34)$ \\
\hline & Absent & $4(40)$ & $4(40)$ & $2(20)$ \\
\hline \multirow{2}{*}{ Perineural invasion } & Present & $10(53)$ & $2(11)$ & $7(36)$ \\
\hline & Absent & $2(22)$ & $6(67)$ & $1(11)$ \\
\hline \multirow[t]{2}{*}{ Tumor margins } & Infiltrative & $10(42)$ & $6(25)$ & $8(33)$ \\
\hline & Infiltrative+expansile & $2(50)$ & $2(50)$ & $0(0)$ \\
\hline \multirow[t]{2}{*}{ Multiple foci } & Present & $5(62)$ & $4(19)$ & 4 (19) \\
\hline & Absent & $7(46)$ & $4(27)$ & $4(27)$ \\
\hline \multirow[t]{2}{*}{ ER } & Negative & $1(33)$ & $2(67)$ & $0(0)$ \\
\hline & Positive & $11(44)$ & $6(24)$ & $8(32)$ \\
\hline \multirow[t]{2}{*}{ PR } & Negative & $3(75)$ & $1(25)$ & $0(0)$ \\
\hline & Positive & $9(38)$ & $7(29)$ & $8(33)$ \\
\hline \multirow[t]{2}{*}{ HER2/neu } & Negative & $11(52)$ & $4(19)$ & $6(29)$ \\
\hline & Positive & $1(14)$ & $4(57)$ & $2(29)$ \\
\hline \multirow[t]{2}{*}{ Ki67 } & High & $8(42)$ & $6(32)$ & $5(26)$ \\
\hline & Borderline+low & $4(44)$ & $2(22)$ & $3(34)$ \\
\hline
\end{tabular}

ER: Estrogen receptor; PR: progesterone receptor; HER2/neu: human epidermal growth factor receptor 2.
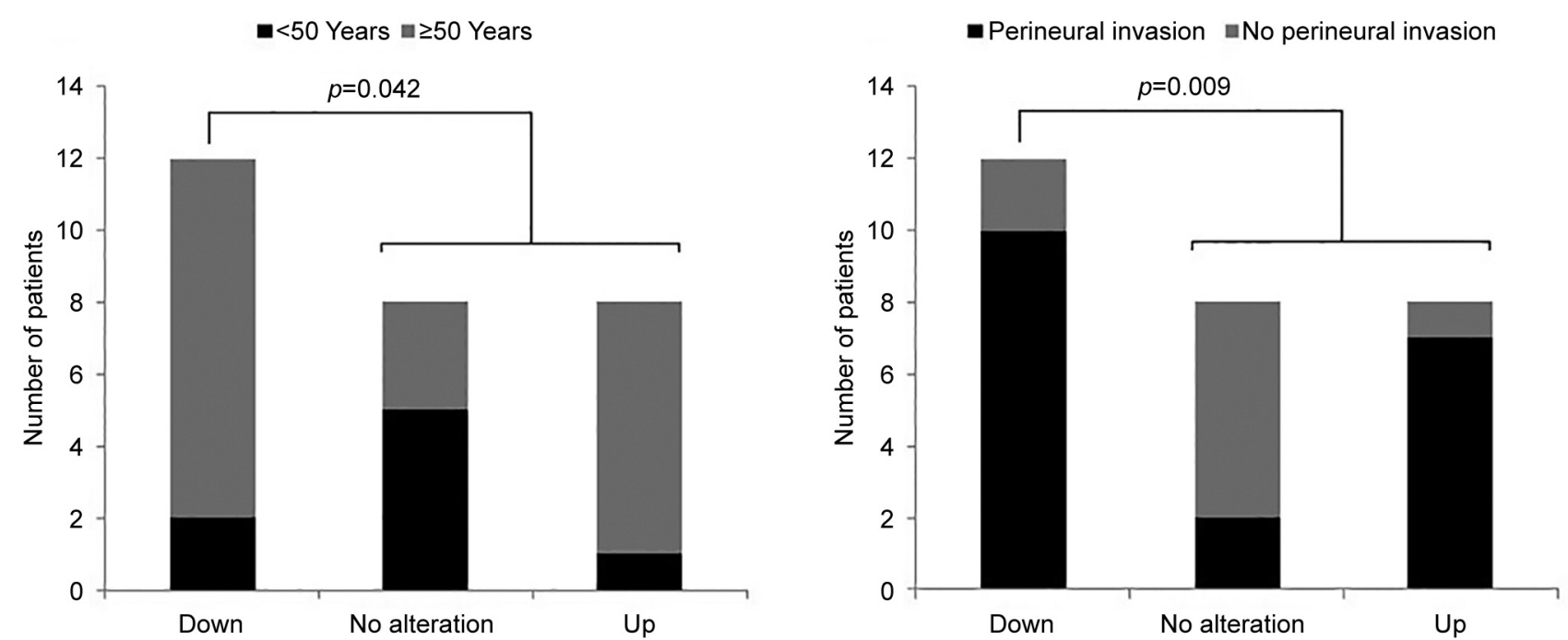

Figure 2. Distribution of the expression levels of kallikrein 11 in association with age and perineural invasion in patients with breast cancer. 
A

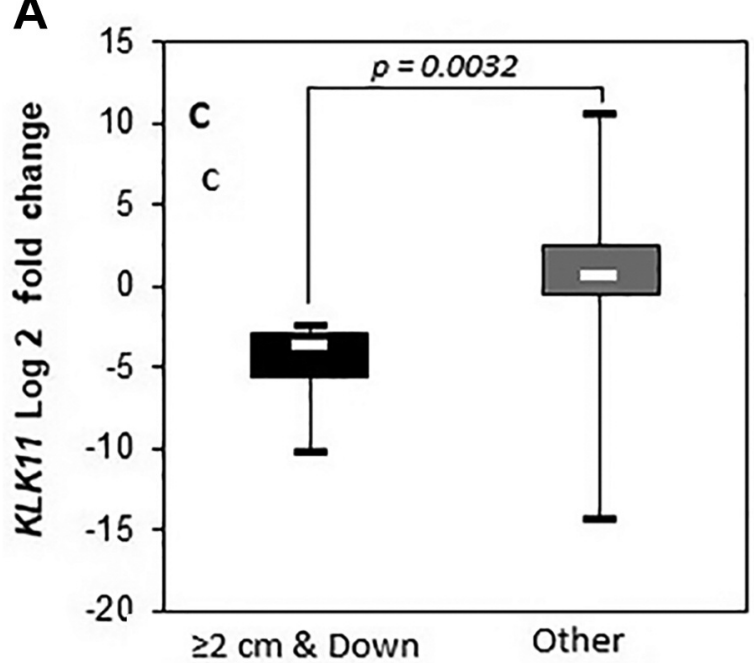

C

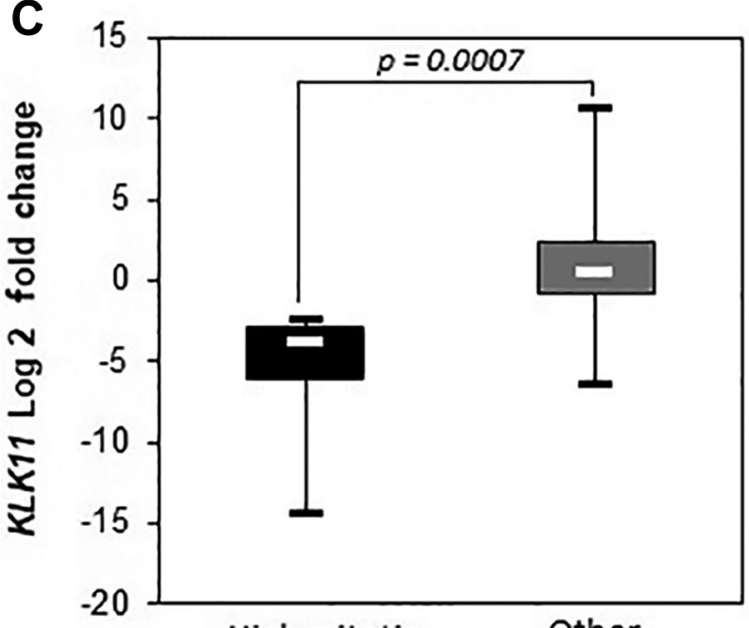

High mitotic

E

score \& Down

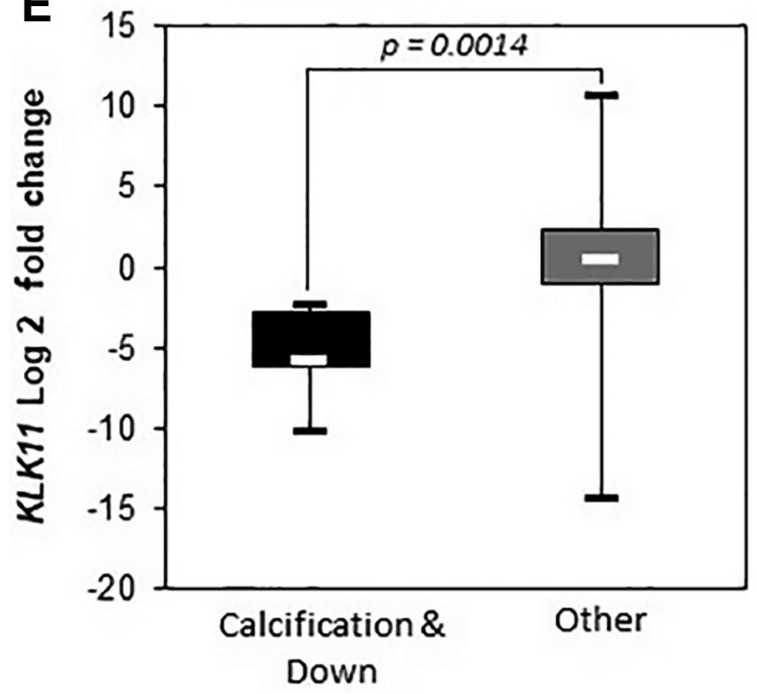

B
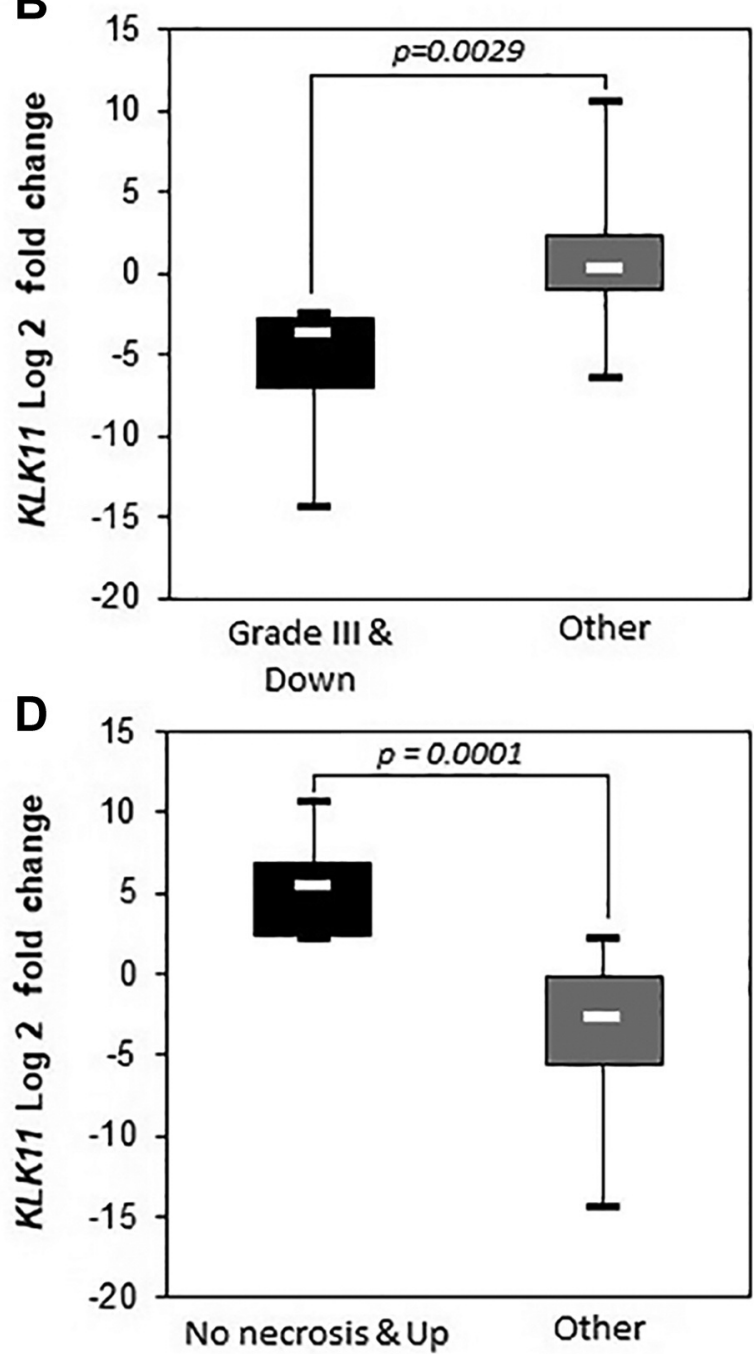

$\mathbf{F}$

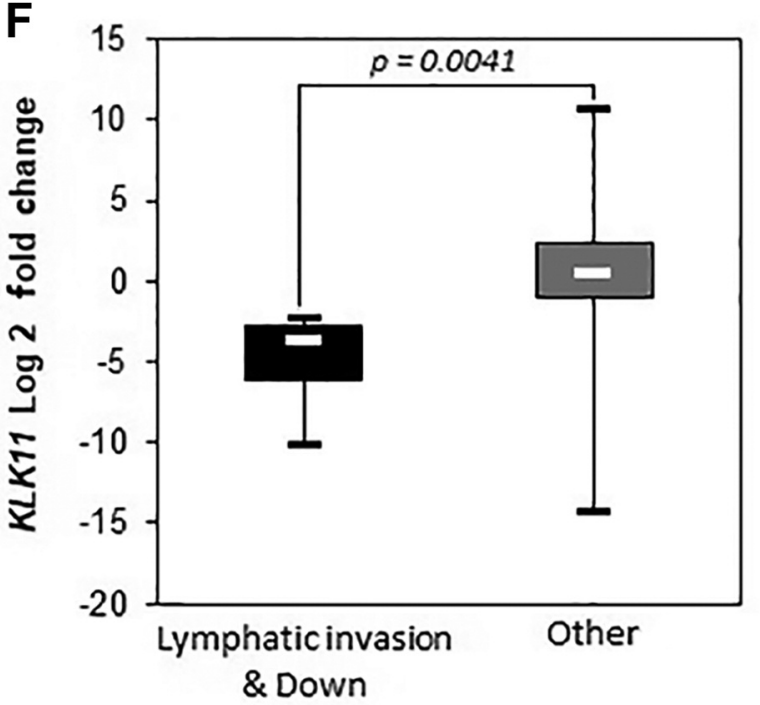

Figure 3. Continued 

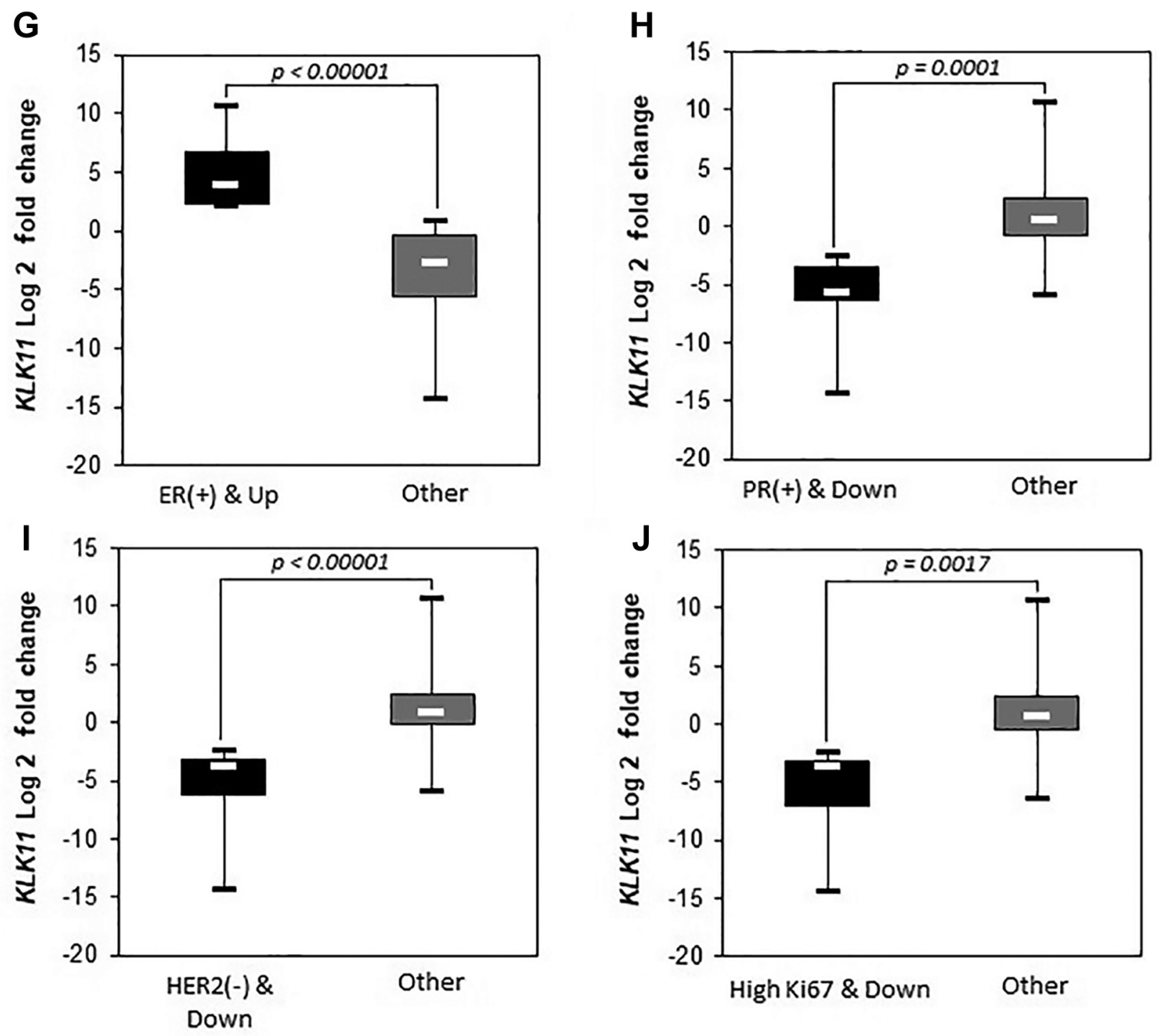

Figure 3. Down-regulation of kallikrein 11 (KLK11) expression significantly $(p<0.05)$ associated with prognostic parameters among patients. ER: Estrogen receptor, PR: progesterone receptor, HER2: human epidermal growth factor receptor 2.

regulation with statistical significance $(p=0.0001$ and $p<0.00001, \mathrm{MU})$. We did not observe a significant difference between the groups regarding prognostic features when we compared the group with no alteration with the rest of the cases.

\section{Discussion}

KLKs have an undisputed role in regulation of tumor growth and metastasis for breast tumors which the observed association with breast tissue development as well as various stages of breast cancer development and progression can be accepted as evidence. Indeed, deregulation of KLK function results in proteolytic activation and aberrant activity of several proteases (other pro-KLKs, matrix metalloproteinases, urokinase-type plasminogen activator), cell surface receptors (e.g. protease-activated receptors, urokinase-type plasminogen activator receptor), growth factors (IGF-binding proteins, latent transforming growth factor $\beta$, and hormones (parathyroid hormone-related protein), all of which result in an accumulation of tumorigenic stimuli and trigger cancer development (26). KLK-dependent dysregulation of the IGF axis results in promitogenic and anti-apoptotic effects on normal and breast tumor cells $(27,28)$. The migration of tumor cells into the surrounding tissues and entry into the circulation are 


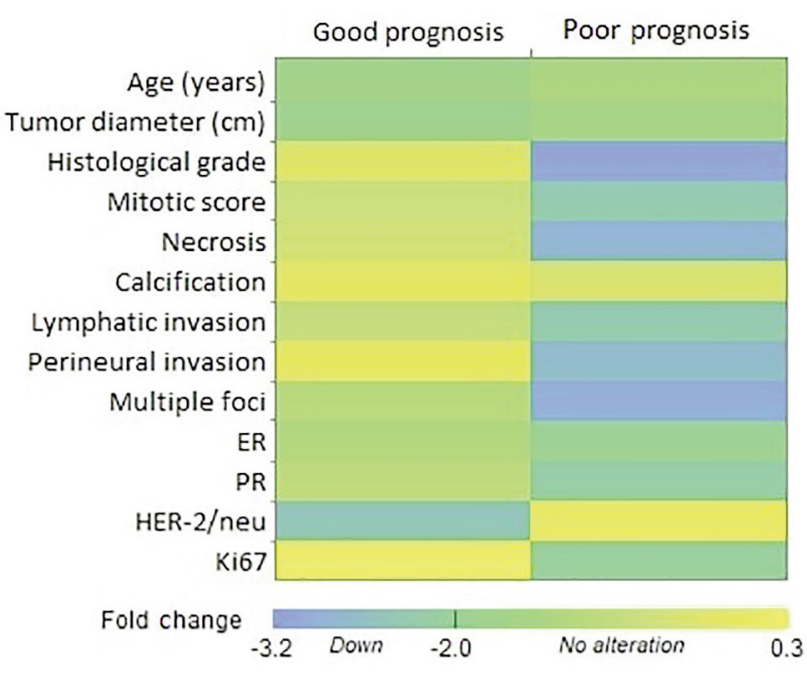

Figure 4. Heatmap of tumor tissue kallikrein 11 expression and prognostic features. The poor prognosis cluster contained most of the highly down-regulated cases. Mean log fold-change values were used to create the heatmap. ER: Estrogen receptor; HER2: human epidermal growth factor receptor; PR: progesterone receptor 2 .

fundamental for cancer dissemination. This process requires proteolysis of ECM proteins, where KLKs are involved both directly by cleaving ECM compounds and indirectly by activation of other ECM-degrading proteases. Numerous studies have been conducted about the KLK11 expression pattern and its association with prognosis (Table I) however there were few studies regarding breast carcinomas (29). When we evaluated our data for KLK11 expression levels together with known prognostic factors (good/poor prognosis) (30), overall, the down-regulations were clustered in favor of poor prognosis, except for age and HER2 expression (Figure 4).

One of the strongest demographic risk factors for human cancer is age (31), with breast cancer rates gradually increasing with age. Although tumors are less common in young women, they do tend to have the aggressive types when they develop it. In previous studies, age is recognized as an important prognostic indicator for breast cancer (32, 33 ), which indicates that young patients with breast cancer generally have a poorer prognosis by comparison with elderly patients at the same clinical stage $(34,35)$. In our study, $K L K 11$ expression in tumor tissues of patients over 50 years old tended to be down-regulated. In this context, KLK11 down-regulation might be a supportive prognostic factor. Our evaluation was based on tumor tissue expression compared to matched peripheral tissue and most of our patients had invasive type carcinoma (25 out of 28); therefore, it is tempting to hypothesize ECM degradation via KLKs may be directed mainly by tumor stromal cells in such cases. A possible stimulus of KLK11 expression in peripheral tissue may be facilitated by secretion of tumor necrosis factor $\alpha$ $(\mathrm{TNF} \alpha)$ from tumor cells. As one of the major inflammatory cytokines, $\mathrm{TNF} \alpha$ is overexpressed in advanced breast cancer cases. Its involvement in a range of different biological responses was observed, for example increased expression of metalloproteases, epithelial-mesenchymal transition, angiogenesis, inflammation, and drug resistance (36-38). In addition, expression of KLKs, including KLK11, were shown to be stimulated via $\mathrm{TNF} \alpha$, together with the expression of B1 bradykinin receptor, which increases cell proliferation and expression/secretion of metalloproteases (21).

Most cases of breast cancer are hormone-dependent (39). KLK activities are altered via regulation of steroid hormones. Thus, they may be downstream targets for hormones which have significant influence on the initiation or progression of breast cancer. Tumors expressing ER and PR tend to be less aggressive, of low grade and have low risk of metastasis and recurrence. The prognosis and response to the treatment are generally good in such cases (40). ER positivity was associated with high KLK11 expression by a previous study (12); however, our results showed the opposite (Figure $3 \mathrm{H}$ ). The discrepancy may be related to the samples used as we conducted our experiments with patient tissue samples (tumor and peripheral breast tissue) not cell lines. Molecular mechanisms between ER signaling and KLK11 regulation are still unclear and need to be investigated further.

Like hormonal receptors, HER2 and Ki67 are also recognized prognostic molecular markers for breast cancer and their overexpression provides an idea about the aggressiveness and the risk of developing recurrence, respectively (38). KLK11 expression was observed to be down-regulated in the presence of Ki67 but not HER2. One possible explanation for this difference is that KLKs, acting as a network, participate in proteolytic pathways that contribute to the neoplastic process (41). Knockdown of KLK11 was shown to suppress the phosphoinositide 3kinase/AKT serine/threonine kinase 1 signaling pathway (42), which induces Ki67 and consequently cell proliferation. The reason we observed high Ki67 index with low KLK11 expression in breast tumor tissues might be due the to the expression of other KLKs. One possible molecular mechanism might be through the cleavage of the extracellular $N$-terminal segment of protease-activated receptors by KLKs, turning on downstream intracellular signaling pathways that activate mitogen-activated protein kinase, which eventually stimulates cell proliferation via increasing Ki67 expression (Figure 5) (43). Analysing the expression of a panel of KLKs in breast cancer tissue samples will give an insight into this phenomenon.

Features such as higher histological grade (44), larger tumor size (45), presence of perineural invasion (46), lymphatic invasion (47) and calcification (48) associated 


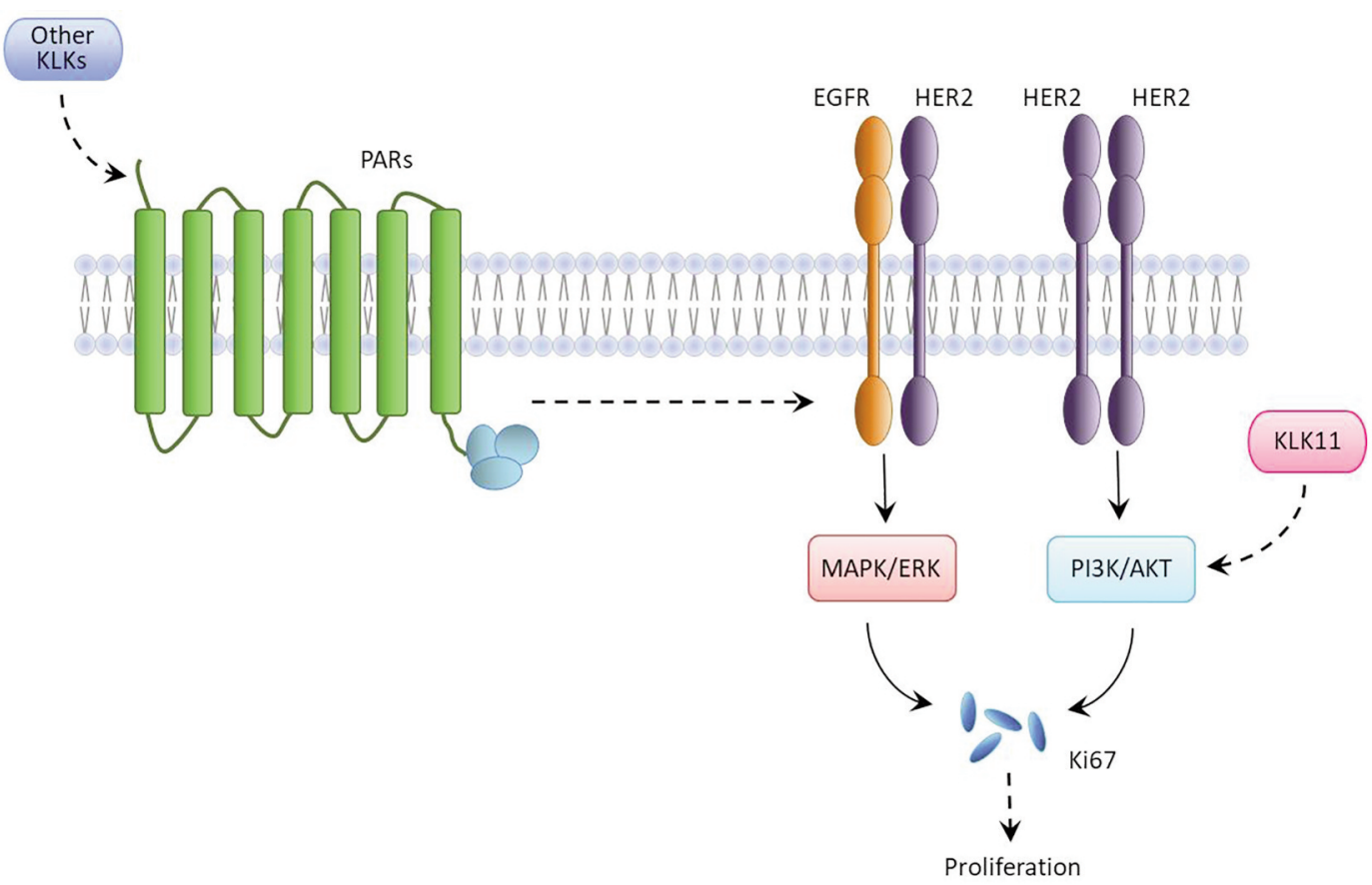

Figure 5. A possible molecular mechanism of breast cancer cell proliferation associated with kallikreins (KLKs), human epidermal growth factor receptor 2 (HER2) and Ki67 expression. Dotted arrows represent stimulation. ER: Estrogen receptor; ERK: extracellular signal-regulated kinase; EGFR: epidermal growth factor receptor; KLK11: kallikrein 11; MAPK: mitogen-activated protein kinase; PI3K: phosphatidylinositol 3-kinase; AKT: protein kinase B; PR: progesterone receptor.

with $K L K 11$ down-regulation in this study are all indicators of stronger proliferation and metastasis. In particular, the significant inverse correlation between histological grade and KLK11 expression that we observed has also been reported by other groups for breast tumor tissue samples (formalin-fixed paraffin-embedded and fresh tissues) (20, 49). Although it is not a definitive result considering the small study group, our findings pointed out that KLK11 expression levels in breast tissue were correlated with these prognostic features.

\section{Conclusion}

Our study is one of the few studies investigating $K L K 11$ expression status in breast cancer. Although our study group was relatively small, to our knowledge this is the first report considering its potential prognostic value in association with the currently used parameters. We observed that expression levels of KLK11 in breast tissue of patients with cancer may have benefits in supporting the prognosis of the disease. Further investigations with larger study groups are needed in order to validate $K L K 11$ down-regulation being associated with prognosis. The role of KLK11 in breast cancer prognosis and its underlying mechanism will be more clearly understood when the KLK network is evaluated as a whole.

\section{Conflicts of Interest}

The Authors declare that no conflicts of interest exist.

\section{Authors' Contributions}

Tülin Öztürk: Conceptualization, project administration, writing original draft preparation and methodology. Ecem Zeynep Kain and Mete Bora Tüzüner: Investigation, resources, and writing - original draft preparation. Ayça Diren: Investigation and resources. Şebnem Batur: Resources. Oğuz Öztürk: Formal analysis. Hülya Yılmaz Aydoğan: Investigation, formal analysis and visualization. Turgay İsbir: Project administration and supervision.

\section{Acknowledgements}

The study was supported by a grant from the Scientific Research Projects Coordination Unit of Istanbul University (Project No: 12974).

\section{References}

1 Walker C, Mojares E and Del Río Hernández A: Role of extracellular matrix in development and cancer progression. Int J Mol Sci 19(10): 3028, 2018. PMID: 30287763. DOI: 10.3390/ ijms 19103028

2 Borgoño CA and Diamandis EP: The emerging roles of human tissue kallikreins in cancer. Nat Rev Cancer 4(11): 876-890, 2004. PMID: 15516960 . DOI: $10.1038 / \mathrm{nrc} 1474$ 
3 Figueroa CD, Molina L, Bhoola KD and Ehrenfeld P: Overview of tissue kallikrein and kallikrein-related peptidases in breast cancer. Biol Chem 399(9): 937-957, 2018. PMID: 29885274. DOI: $10.1515 / \mathrm{hsz}-2018-0111$

4 Mangé A, Desmetz C, Berthes ML, Maudelonde T and Solassol $\mathrm{J}$ : Specific increase of human kallikrein 4 mRNA and protein levels in breast cancer stromal cells. Biochem Biophys Res Commun 375(1): 107-112, 2008. PMID: 18687310. DOI: 10.1016/j.bbrc.2008.07.138

5 Shaw JL and Diamandis EP: Distribution of 15 human kallikreins in tissues and biological fluids. Clin Chem 53(8): 1423-1432, 2007. PMID: 17573418. DOI: 10.1373/clinchem. 2007.088104

6 Bayani J, Petraki CD, Dimitromanolakis A, Milou V, Diamandis EP and Schmitt M: Expression of kallikrein-related peptidases under (patho-)physiological conditions. In:Kallikrein-related peptidases Volume 1 Characterization, Regulation, and Interactions Within the Protease Web. Magdolen V, Sommerhoff CP, Fritz H and Schmitt M (eds.).Berlin/Boston, Walter de Gruyter GmbH, pp 219-221, 2012.

7 McIntosh MW, Liu Y, Drescher C, Urban N and Diamandis EP: Validation and characterization of human kallikrein 11 as a serum marker for diagnosis of ovarian carcinoma. Clin Cancer Res 13(15 Pt 1): 4422-4428, 2007. PMID: 17671125. DOI: 10.1158/1078-0432.CCR-06-2224

8 Mitsui S, Yamada T, Okui A, Kominami K, Uemura $\mathrm{H}$ and Yamaguchi N: A novel isoform of a kallikrein-like protease, TLSP/hippostasin, (PRSS20), is expressed in the human brain and prostate. Biochem Biophys Res Commun 272(1): 205-211, 2000. PMID: 10872828. DOI: 10.1006/bbrc.2000.2761

9 Stavropoulou P, Gregorakis AK, Plebani M and Scorilas A: Expression analysis and prognostic significance of human kallikrein 11 in prostate cancer. Clin Chim Acta 357(2): 190-195, 2005. PMID: 15893744. DOI: 10.1016/j.ccen.2005.03.026

10 Andreopoulou E and Hortobagyi GN: Prognostic factors in metastatic breast cancer: successes and challenges toward individualized therapy. J Clin Oncol 26(22): 3660-3662, 2008. PMID: 18669447. DOI: 10.1200/JCO.2008.16.1026

$11 \mathrm{Yu} \mathrm{X}$, Tang HY, Li XR, He XW and Xiang KM: Overexpression of human kallikrein 11 is associated with poor prognosis in patients with low rectal carcinoma. Med Oncol 27(1): 40-44, 2010. PMID: 19184568. DOI: 10.1007/s12032009-9167-2

12 Jamaspishvili T, Scorilas A, Kral M, Khomeriki I, Kurfurstova D, Kolar Z and Bouchal J: Immunohistochemical localization and analysis of kallikrein-related peptidase 7 and 11 expression in paired cancer and benign foci in prostate cancer patients. Neoplasma 58(4): 298-303, 2011. PMID: 21520985.

13 Patsis C, Yiotakis I and Scorilas A: Diagnostic and prognostic significance of human kallikrein 11 (KLK11) mRNA expression levels in patients with laryngeal cancer. Clin Biochem 45(9): 623-630, 2012. PMID: 22429520. DOI: 10.1016/j.clinbiochem. 2012.03.005

14 Alexopoulou DK, Kontos CK, Christodoulou S, Papadopoulos IN and Scorilas A: KLK11 mRNA expression predicts poor disease-free and overall survival in colorectal adenocarcinoma patients. Biomark Med 8(5): 671-685, 2014. PMID: 25123036. DOI: $10.2217 / \mathrm{bmm} .13 .151$

15 Kolin DL, Sy K, Rotondo F, Bassily MN, Kovacs K, BrezdenMasley C, Streutker CJ and Yousef GM: Prognostic significance of human tissue kallikrein-related peptidases 11 and 15 in gastric cancer. Tumour Biol 37(1): 437-446, 2016. PMID: 26224476. DOI: $10.1007 / \mathrm{s} 13277-015-3802-7$

16 Unal D, Eroglu C, Tasdemir A, Karaman H, Kurtul N, Oguz A, Goksu SS and Kaplan B: Is human kallikrein 11 in non-small cell lung cancer treated chemoradiotherapy associated with survival? Cancer Res Treat 48(1): 98-105, 2016. PMID: 25779361. DOI: $10.4143 /$ crt.2014.364

17 Geng X, Liu Y, Diersch S, Kotzsch M, Grill S, Weichert W, Kiechle M, Magdolen V and Dorn J: Clinical relevance of kallikrein-related peptidase $9,10,11$, and $15 \mathrm{mRNA}$ expression in advanced highgrade serous ovarian cancer. PLoS One 12(11): e0186847, 2017. PMID: 29095848. DOI: 10.1371/journal.pone.0186847

18 He X, Meng F, Qin L, Liu Z, Zhu X, Yu Z and Zheng Y: KLK11 suppresses cellular proliferation via inhibition of Wnt//3-catenin signaling pathway in esophageal squamous cell carcinoma. Am J Cancer Res 9(10): 2264-2277, 2019. PMID: 31720087.

19 Schmitt M, Magdolen V, Yang F, Kiechle M, Bayani J, Yousef GM, Scorilas A, Diamandis EP and Dorn J: Emerging clinical importance of the cancer biomarkers kallikrein-related peptidases (KLK) in female and male reproductive organ malignancies. Radiol Oncol 47(4): 319-329, 2013. PMID: 24294176. DOI: $10.2478 /$ raon-2013-0053

20 Sano A, Sangai T, Maeda H, Nakamura M, Hasebe T and Ochiai A: Kallikrein 11 expressed in human breast cancer cells releases insulin-like growth factor through degradation of IGFBP-3. Int J Oncol 30(6): 1493-1498, 2007. PMID: 17487371.

21 Ehrenfeld P, Manso L, Pavicic MF, Matus CE, Borquez C, Lizama A, Sarmiento J, Poblete MT, Bhoola KD, Naran A and Figueroa CD: Bioregulation of kallikrein-related peptidases 6, 10 and 11 by the kinin $B_{1}$ receptor in breast cancer cells. Anticancer Res 34(12): 6925-6938, 2014. PMID: 25503118.

22 Oliveras-Ferraros C, Vazquez-Martin A, Cuyàs E, Corominas-Faja B, Rodríguez-Gallego E, Fernández-Arroyo S, Martin-Castillo B, Joven J and Menendez JA: Acquired resistance to metformin in breast cancer cells triggers transcriptome reprogramming toward a degradome-related metastatic stem-like profile. Cell Cycle 13(7): 1132-1144, 2014. PMID: 24553122. DOI: 10.4161/cc.27982

23 Hortobagyi GN, Connolly JL, D’Orsi CJ, Edge SB, Mittendorf EA, Rugo HS, Solin LJ, Weaver DL, Winchester DJ and Giuliano A: Breast. In: AJCC Cancer Staging Manual, Eighth Edition. Amin MB (ed.). Chicago, American College of Surgeons, pp 587-636, 2017.

24 Tüzüner MB, Öztürk T, Eronat AP, Seyhan F, Kısakesen Hİ, Calay Z, İlvan Ş, Turna H, Yılmaz-Aydoğan H, Bermek H and Öztürk O: Evaluation of local CYP17A1 and CYP19A1 expression levels as prognostic factors in postmenopausal invasive ductal breast cancer cases. Biochem Genet 54(6): 784802, 2016. PMID: 27365044. DOI: 10.1007/s10528-016-9756-7

25 Livak KJ and Schmittgen TD: Analysis of relative gene expression data using real-time quantitative PCR and the 2(Delta Delta C(T)) Method. Methods 25(4): 402-408, 2001. PMID: 11846609. DOI: 10.1006/meth.2001.1262

26 Avgeris M, Mavridis K and Scorilas A: Kallikrein-related peptidases in prostate, breast, and ovarian cancers: from pathobiology to clinical relevance. Biol Chem 393(5): 301-317, 2012. PMID: 22505514. DOI: 10.1515/hsz-2011-0260

27 Lundwall A: Old genes and new genes: the evolution of the kallikrein locus. Thromb Haemost 110(3): 469-475, 2013. PMID: 23571662. DOI: 10.1160/TH12-11-0851 
28 Pignataro L, Sambataro G, Pagani D and Pruneri G: Clinicoprognostic value of D-type cyclins and p27 in laryngeal cancer patients: a review. Acta Otorhinolaryngol Ital 25(2): 75-85, 2005. PMID: 16116829.

29 Mavridis K and Scorilas A: Prognostic value and biological role of the kallikrein-related peptidases in human malignancies. Future Oncol 6(2): 269-285, 2010. PMID: 20146586. DOI: 10.2217/fon.09.149

30 Donegan WL: Tumor-related prognostic factors for breast cancer. CA Cancer J Clin 47(1): 28-51, 1997. PMID: 8996077. DOI: $10.3322 /$ canjclin.47.1.28

31 Benz CC and Yau C: Ageing, oxidative stress and cancer: paradigms in parallax. Nat Rev Cancer 8(11): 875-879, 2008. PMID: 18948997. DOI: $10.1038 /$ nrc2522

32 Dabakuyo TS, Bonnetain F, Roignot P, Poillot ML, Chaplain G, Altwegg T, Hedelin G and Arveux P: Population-based study of breast cancer survival in Cote d'Or (France): prognostic factors and relative survival. Ann Oncol 19(2): 276-283, 2008. PMID: 17962200. DOI: 10.1093/annonc/mdm491

33 Anders CK, Acharya CR, Hsu DS, Broadwater G, Garman K, Foekens JA, Zhang Y, Wang Y, Marcom K, Marks JR, Mukherjee S, Nevins JR, Blackwell KL and Potti A: Agespecific differences in oncogenic pathway deregulation seen in human breast tumors. PLoS One 3(1): e1373, 2008. PMID: 18167534. DOI: 10.1371/journal.pone.0001373

34 Woodward WA and Buchholz TA: Should breast conservation be offered to young women with breast cancer? Breast Cancer Res Treat 127(1): 217-219, 2011. PMID: 20945088. DOI: 10.1007/ s10549-010-1205-4

35 Emiroğlu M, Karaali C, Sert İ, Salimoğlu S, Uğurlu L, Aksoy S and Aydın C: Comparison of clinical and pathological differences of breast cancer patients under 35 and above 55 years of age. J Breast Health 11(3): 123-127, 2015. PMID: 28331706. DOI: $10.5152 /$ tjbh.2015.2539

36 Madhusudan S, Foster M, Muthuramalingam SR, Braybrooke JP, Wilner S, Kaur K, Han C, Hoare S, Balkwill F, Talbot DC, Ganesan TS and Harris AL: A phase II study of etanercept (Enbrel), a tumor necrosis factor alpha inhibitor in patients with metastatic breast cancer. Clin Cancer Res 10(19): 6528-6534, 2004. PMID: 15475440. DOI: 10.1158/1078-0432.CCR-04-0730

37 Morizane S, Yamasaki K, Kabigting FD and Gallo RL: Kallikrein expression and cathelicidin processing are independently controlled in keratinocytes by calcium, vitamin D(3), and retinoic acid. J Invest Dermatol 130(5): 1297-1306, 2010. PMID: 20090765. DOI: 10.1038/jid.2009.435

38 Esteva FJ and Hortobagyi GN: Prognostic molecular markers in early breast cancer. Breast Cancer Res 6(3): 109-118, 2004. PMID: 15084231. DOI: 10.1186/bcr777

39 Hormone Therapy for Breast Cancer. American Cancer Society, 2019. Available at https://www.cancer.org/cancer/breast-cancer/ treatment/hormone-therapy-for-breast-cancer.html [Last accessed on $19^{\text {th }}$ September, 2021]
40 Moffat FL: Clinical and pathologic prognostic and predictive factors. In: Diseases of the Breast, 5th edition. Harris JR, Lippman ME, Morrow M, Osborne CK (eds.), Philadelphia, Lippincott Williams \& Wilkins,pp 439-452, 2014.

41 Stefanini AC, da Cunha BR, Henrique T and Tajara EH: Involvement of Kallikrein-Related Peptidases in Normal and Pathologic Processes. Dis Markers 2015: 946572, 2015. PMID: 26783378. DOI: $10.1155 / 2015 / 946572$

42 Zhang Y, Xu Z, Sun Y, Chi P and Lu X: Knockdown of KLK11 reverses oxaliplatin resistance by inhibiting proliferation and activating apoptosis via suppressing the PI3K/AKT signal pathway in colorectal cancer cell. Onco Targets Ther 11: 809821, 2018. PMID: 29497313. DOI: 10.2147/OTT.S151867

43 Kryza T, Silva ML, Loessner D, Heuzé-Vourc'h N and Clements JA: The kallikrein-related peptidase family: Dysregulation and functions during cancer progression. Biochimie 122: 283-299, 2016. PMID: 26343558. DOI: 10.1016/j.biochi.2015.09.002

44 Rakha EA, Reis-Filho JS, Baehner F, Dabbs DJ, Decker T, Eusebi V, Fox SB, Ichihara S, Jacquemier J, Lakhani SR, Palacios J, Richardson AL, Schnitt SJ, Schmitt FC, Tan PH, Tse GM, Badve S and Ellis IO: Breast cancer prognostic classification in the molecular era: the role of histological grade. Breast Cancer Res 12(4): 207, 2010. PMID: 20804570. DOI: $10.1186 / \mathrm{bcr} 2607$

45 Rosenberg J, Chia YL and Plevritis S: The effect of age, race, tumor size, tumor grade, and disease stage on invasive ductal breast cancer survival in the U.S. SEER database. Breast Cancer Res Treat 89(1): 47-54, 2005. PMID: 15666196. DOI: 10.1007/ s10549-004-1470-1

46 Karak SG, Quatrano N, Buckley J and Ricci A Jr: Prevalence and significance of perineural invasion in invasive breast carcinoma. Conn Med 74(1): 17-21, 2010. PMID: 20175368.

47 Rakha EA, Martin S, Lee AH, Morgan D, Pharoah PD, Hodi Z, Macmillan D and Ellis IO: The prognostic significance of lymphovascular invasion in invasive breast carcinoma. Cancer 118(15): 3670-3680, 2012. PMID: 22180017. DOI: 10.1002/ cncr.26711

48 Rizwan A, Paidi SK, Zheng C, Cheng M, Barman I and Glunde $\mathrm{K}$ : Mapping the genetic basis of breast microcalcifications and their role in metastasis. Sci Rep 8(1): 11067, 2018. PMID: 30038419. DOI: 10.1038/s41598-018-29330-9

49 Bakaeean B, Gholamin M, Tabatabaee Yazdi SA and Forghani MN: Novel biomarkers aim at detecting metastatic sentinel lymph nodes in breast cancer. Iran Biomed J 24(3): 183-191, 2020. PMID: 31983196. 